\title{
Bangiopsis subsimplex (Mont.) F. Schmitz (Stylonematales, Rhodophyta) on the northeastern coast of Brazil ${ }^{1}$
}

\author{
Wellington Romualdo de Almeida ${ }^{2,4}$, Silvia Maria Pita de Beauclair Guimarães ${ }^{3}$ \\ and Carlos Wallace do Nascimento Moura ${ }^{2}$
}

Submitted: 13 July, 2012. Accepted: 8 November, 2012

\begin{abstract}
We report here the first occurrence of Bangiopsis subsimplex (Mont.) F.Schmitz (Rhodophyta) for the northeastern coast of Brazil. The specimen was isolated from a laboratory sample of mollusk shells collected in Baía de Todos os Santos (Bimbarras Island, Brazil) and was held in sterilized seawater (33 UPS) enriched with 25\% Provasoli solution. In the American Atlantic region, B. subsimplex presents a northern distribution limit at French Guiana and a southern limit at São Paulo. We conclude that the distribution of B. subsimplex has expanded, since the species was once known only to the southeastern Brazil, specifically to São Paulo.
\end{abstract}

Key words: Marine algae, Bahia, Baía de Todos os Santos, Stylonemaceae, Taxonomy

Bangiopsis F.Schmitz (Rhodophyta, Stylonematophyceae) is one of 13 genera in the order Stylonematales (West et al. 2007). Morphologically, species in this genus are characterized by a flexible, filamentous thallus, with the younger portions uniseriate and older portions multiseriate and thicker; ramifications, when present, are sparse, subdichotomous to regular, and sometimes have short and uniseriate proliferations on the thallus; the cells are rounded, and have star-shaped chloroplasts with pyrenoids; reproduction occurs by way of monosporangia (Børgesen 1915; Krishnamurthy 1957; West et al. 2005).

The genus has a disjunct geographical distribution. A study by Guiry \& Guiry (2012) presents sparse records from marine and estuary environments in Japan, the Fiji Islands, Southeast Asia (India, Pakistan, Sri Lanka and Vietnam) and the western Atlantic (Virgin Islands, Cuba, Jamaica, Hispaniola, Guyana, Columbia and Brazil). There are currently two recognized species of Bangiopsis: B. dumontioides
V.Krishnam (P.Crouan \& H.Crouan in Schramm \& Mazé) and B. subsimplex F.Schimtz, both described for the western Atlantic by Wynne (2011).

In Brazil, the genus Bangiopsis was previously known only to the southeastern coast. Creed et al. (2012) reported the occurrence of $B$. dumontioides for the state of Rio de Janeiro (based on Brasileiro et al. 2009) and B. subsimplex along the coast of the state of São Paulo (based on Joly 1965). However, this work referred only to a single species of Bangiopsis, identified as B. humphreyi (Collins) G.Hamel (= B. dumontioides) and probably represents an erroneous identification of B. subsimplex. In examining the molecular phylogeny of Porphyra species found along the Brazilian coast, Milstein \& Oliveira (2005) also sequenced specimens of Bangiopsis species from Cardoso Island, São Paulo (initially identified as Bangia fuscopurpurea (Dillwyn) Lyngb.). However, after obtaining small-subunit ribosomal DNA sequences, they concluded that the specimen was in fact B. subsimplex.

\footnotetext{
${ }^{1}$ Based on the Master's dissertation of the first Author

${ }^{2}$ Universidade Estadual de Feira de Santana, Departamento de Ciências Biológicas, Programa de Pós-Graduação em Botânica, Laboratório de Ficologia, Feira de Santana, BA, Brazil

${ }^{3}$ Instituto de Botânica, Núcleo de Pesquisa de Ficologia, São Paulo, SP, Brazil

${ }^{4}$ Author for correspondence: romualdowellington@gmail.com
} 
The present study presents the first record of B. subsimplex for the northeastern coast of Brazil and describes the morphologic characteristics of the specimens encountered.

The B. simplex specimens were obtained from mollusk shells collected on Bimbarras Island in the municipality of São Francisco do Conde, which is located in the northern region of Baía de Todos os Santos, Brazil (1243'29"S; $\left.38^{\circ} 38^{\prime} 09^{\prime \prime} \mathrm{W}\right)$. The shells were transferred to small cultivation flasks ( $140 \mathrm{ml}$ baby food jars) containing sterilized seawater (33 UPS) enriched with 25\% Provasoli solution (Provasoli 1968). The media was renewed every two weeks. The specimens were cultivated in stagnant cultures at $22 \pm 1^{\circ} \mathrm{C}$ under a horizontal bank of cold white fluorescent lamps $\left(30 \pm 5 \mu \mathrm{mol}\right.$ of photons $\left.\mathrm{m}^{-2} \mathrm{~s}^{-1}\right)$, on a 12/12-h light/ dark cycle (Bravin et al. 2006).

The morphological and anatomical characters of $B$. subsimplex were analyzed by stereo and light microscopy, with an ocular micrometer and a coupled digital microscope camera. The dimensions recorded (diameter and length) were determined by making between 10 and 20 measurements of randomly chosen specimens.

After the analyses, the specimens were deposited in the Herbarium of the Universidade Estadual de Feira de Santana (HUEFS, Feira de Santana State University).

B. subsimplex (Mont.) F.Schimitz, Beih., Die natürlichen Pflanzenfamilien ... I. Teil, Abt. 2: 315. 1896. Compsopogon subsimplex Mont., Ann. Sci. Nat. Bot., ser. 3, 14: 299-300. 1850.

Fig. 1A-J

Thallus diminutive, reddish-vinaceous colored, composed of a flexible filament, gelatinous, up to $1.5 \mathrm{~mm}$ long, fixed to the substrate by a basal disk. Thallus formed by a filiform axis, uniseriate in the apical region but becoming irregularly multiseriate, $3-6$ cells in the basal and median regions; short and long uniseriate proliferations present on the basal portion of the thallus. Ramifications not observed. Apical region of the filament 18-(19.9)-23.7 $\mu \mathrm{m}$ in diameter, becoming thicker in the median and basal regions, up to 35-(48.7)-50 $\mu \mathrm{m}$ in diameter. Cells small, wrapped in individual sheaths, spaced one from the other by a common gelatinous mass; apical cells cylindrical, apex rounded; subapical cells subcircular to squarish, 7.5-(10)-12.5 $\mu \mathrm{m}$ long and 7.5-(7.5)-10 $\mu \mathrm{m}$ in diameter, sometimes arranged transversely in the filament; medianbasal cells circular to subcircular, 7.5-(10)-12.5 $\mu \mathrm{m}$ long and 5-(7.5)-10 $\mu \mathrm{m}$ in diameter; chloroplasts star-shaped, with an evident central pyrenoid. Reproductive structures not observed.

Material examined: BRAZIL. Bahia: São Francisco do Conde, Bimbarras Island, 03/VII/2011, Almeida, W.R. \& Neto, E.B.S. s.n. (HUEFS 185433).

B. subsimplex was not common in the study area. It was encountered under in vitro culture conditions, growing on the shells of mollusks that had been collected in sandy/ muddy substrate sites and adhering to the walls of cultivation flasks in association with Derbesia species.

Among the filamentous genera in the order Stylonematales, Bangiopsis is morphologically similar to Purpureofilum J.A.West, G.C.Zuccarello \& J.L.Scott, although the latter is distinguished by having a diminutive thallus (up to $1 \mathrm{~mm}$ ), unicellular basal system, cells with a multiple-lobed single chloroplast without a pyrenoid and non-mobile spores not formed in packets (West et al. 2005).

West et al. (2007) examined partial sequences of smallsubunit RNA and the psbA gene (DNA) and observed that in the resulting consensus tree (maximum-likelihood topology) the genera Bangiopsis and Purpureofilum grouped together with Rhodaphanes J.A.West, G.C.Zuccarello, J.L.Scott \& K.A.West - a genus with a diminutive thallus and which is morphologically similar to Stylonema Reinsch. According to those authors, Rhodaphanes is distinct from Bangiopsis and Purpureofilum in that its species have cells with one parietal multilobed chloroplast and without a peripheral encircling thylakoid (a feature not seen in any other genus of the class Stylomenatophyceae), as well as cell walls with digeneaside, sorbitol, and trehalose as their principal low molecular weight carbohydrates.

B. subsimplex was proposed by Schmitz (1896) based on Compsopogon subsimplex, a taxon described by Montagne (1850) from material collected by Leprieur in Caiena, French Guiana (Bryant \& Irvine 2002). Schmitz categorized the species as a doubtful member of the family Bangiaceae, although Drew (1956) transferred it to the family Stylonemataceae together with other genera of unicellular, filamentous or pseudofilamentous algae.

B. subsimplex is morphologically similar to $B$. dumontioides, although the latter differs by having a thicker thallus and multiseriate primary ramifications (Børgesen 1915; Krishnamurthy 1957).

The specimens from Bimbarras Island that were identified as B. subsimplex coincided precisely with the descriptions by Montagne (1850, as Compsopogon subsimplex) and Børgesen (1915). The specimens also coincided, in part, with descriptions by Krishnamurthy (1957) and West et al. (2005), although those authors described thalli with ramifications - a characteristic not observed in the specimens examined here.

No reproductive structures were observed in the specimens analyzed; however, according to West et al. (2005), B. subsimplex reproduces by way of monospores that migrate through shuffling (when tails are absent) or brief movement (when tails are present). The spores are formed either independently or in small packets enclosed within a matrix. These spore packets contain 5-20 spores and the cell division patterns give the packets a polyhedral parenchymatous appearance (West et al. 2005).

In the western Atlantic region, the distribution area of B. subsimplex ranges from French Guiana in the north to São Paulo in the south. Therefore, we are able to conclude 

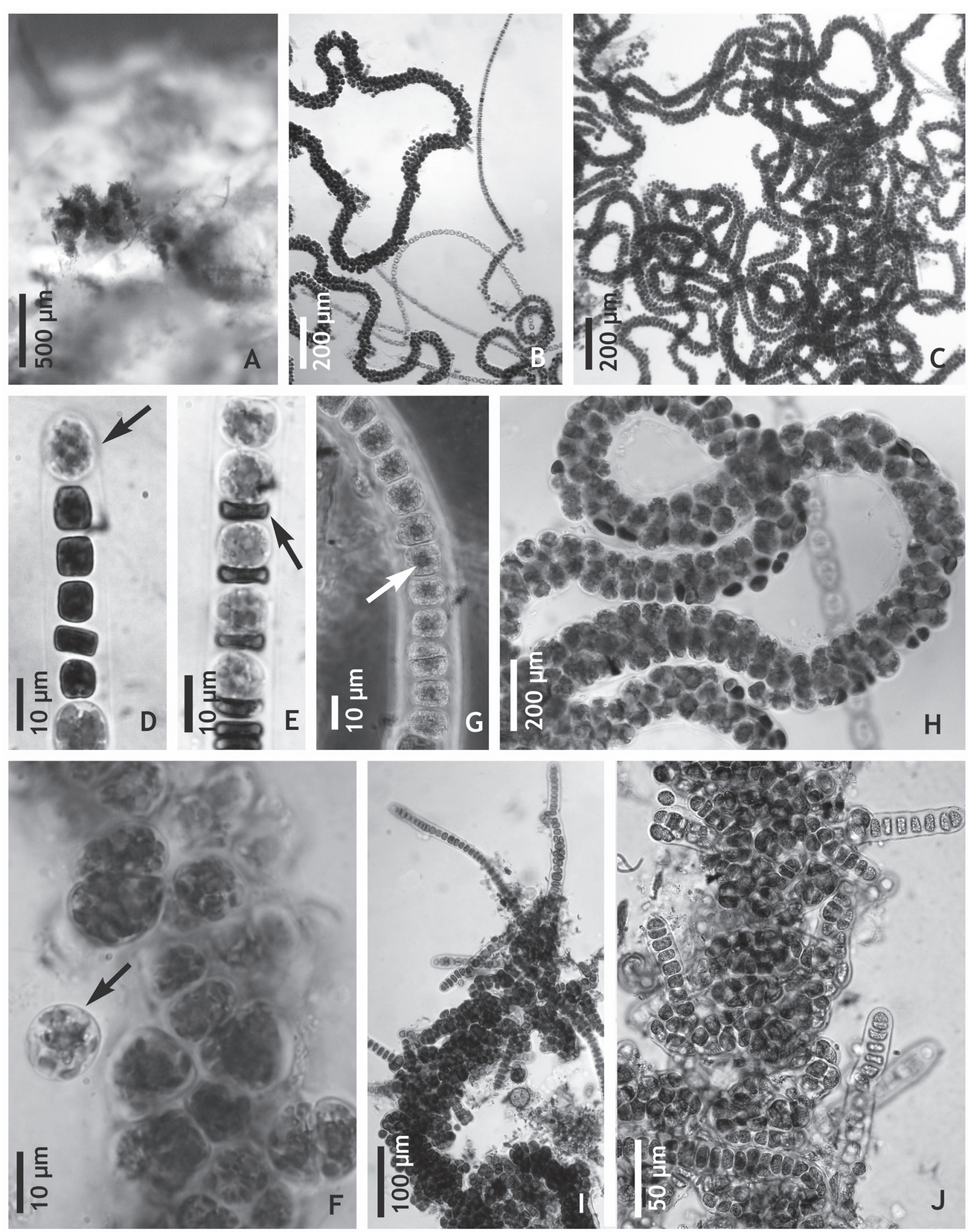

Figure 1. B. subsimplex (Mont.) F.Schmitz. A. General aspect of the thallus growing on a mollusk shell. B. Filament showing the uniseriate apical region with posterior thickenings. C. Filiform and flexuous filament. D. Apical cell (arrow). E. Subapical cells; note the transversal cell arrangement in the filament (arrow). F. Detail of the basal region cells; note the cell with a star-shaped chloroplast (arrow). G. Detail of the apical region cells; note the cells with evident pyrenoids (arrow), seen by interference contrast microscopy. H. Detail of the multiseriate portion of the thallus; note the irregular cell placement. I-J. Short or long uniseriate proliferations originating in the basal region of the thallus. 
that the distribution area of B. subsimplex has grown along the Brazilian coast, as this species was once known only to the southeastern region of the country, specifically along the coast of the state of São Paulo (Creed et al. 2012).

\section{Acknowledgements}

The authors would like to thank the Brazilian Conselho Nacional de Desenvolvimento Cientifico e Tecnológico (CNPq, National Counsel of Technological and Scientific Development) for the Masters grant awarded to WRA; the Fundação de Amparo à Pesquisa do Estado da Bahia (FAPESB, Foundation for Research Support of the State of Bahia, Proc. PPP 0011/2006); the Fundação de Apoio à Pesquisa e à Extensão da Universidade Federal da Bahia (UFBA/ FAPEX, Foundation for Research and Outreach Support of the Federal University of Bahia, Proc. 049/2008); Projeto Flora da Bahia (Flora Project of Bahia); and the Universidade Estadual de Feira de Santana (UEFS, Feira de Santana State University) for their support.

\section{References}

Børgesen, F. 1915. The Marine Algae of the Danish West Indies. Part 3. Rhodophyceae. Dansk Botanisk Arkiv 3: 1-80.

Barros-Barreto, M.B.B.; Brasileiro, P.S.; Nunes, J.M.C. \& Filho, G.M.A. 2004. Algas marinhas bentônicas do sublitoral das formações recifais da Baía de Todos os Santos, BA - 1. Novas ocorrências. Hoehnea 31(3): 321-330.

Brasileiro, P.S.; Yoneshigue-Valentin, Y.; Bahia, R.G.; Reis, R.P. \& Amado Filho, G.M. 2009. Algas marinhas bentônicas da região de Cabo Frio e arredores: síntese do conhecimento. Rodriguésia 60 (1): 39-66.

Bravin, I.C.; Valentin, Y.Y. \& Yokoya, N. 2006. Formação de calos e regeneração de segmentos apicais de Hypnea musciformis (Wulfen) Lamouroux (Gigartinales, Rhodophyta): obtenção de culturas axênicas e efeitos da concentração do ágar. Revista Brasileira de Botânica 29(1): 175-182.
Bryant, J.A. \& Irvine, L.M. 2002. The Schmitz Slide Collection at the Natural History Museum, London (BM). Constancea 83.3. http:// ucjeps.berkeley.edu/constancea/83/ (Accessed in 20/06/2012).

Cirano, M. \& Lessa, G.C. 2007. Oceanographic characteristics of Baía de Todos os Santos, Brazil. Revista Brasileira de Geofísica 25(4): 363-387.

Creed, M.; Nunes, J.M.C.; Moura, C.W.N.; Fujii, M.T.; Cassano, V.; BarrosBarreto, M.B.B.; Pereira, S.M.B.; Khader, S.; Necchi Jr., O.; Oliveira, M.C.; Henriques, M.C.; Oliveira-Carvalho, M.F. \& Guimarães, S.M.P.B. 2012. Rhodophyceae in Lista de Espécies da Flora do Brasil. Jardim Botânico do Rio de Janeiro. http://floradobrasil.jbrj.gov.br/2012/ FB099625 (Accessed in 20/06/2012).

Drew, K.M. 1956. Conferva ceramicola Lyngbye. Botanisk Tidsskrift 53: 67-74.

Guiry, M.D. \& Guiry, G.M. 2012. AlgaeBase. World-wide electronic publication, National University of Ireland, Galway. http://www.algaebase. org (Acessed in 20/05/2012).

Joly, A.B. 1965. Flora marinha do litoral Norte do Estado de São Paulo e regiões circunvizinhas. Boletim da Faculdade de Filosofia, Ciências e Letras da Universidade de São Paulo, Série Botanica 21 (292): 5-393.

Krishnamurthy, V. 1957. The genus Bangiopsis Schmitz from South India. Phytomorphology 7(2): 102-112.

Montagne, C. 1850. Pugillus algarum yemensium, quas collegerunt annis 1847-1849, clarr. Arnaud et Vaysière. Annales des Sciences Naturelles, Botanique, série 3, 14: 236-248.

Milstein, D. \& Oliveira, M.C. 2005. Molecular phylogeny of Bangiales (Rhodophyta) based on small subunit rDNA sequencing: emphasis on Brazilian Porphyra species. Phycologia 44(2): 212-221.

Provasoli, L. 1968. Media and prospects for cultivation of marine algae. Pp. 47-74. In: A. Watanase \& A. Hattori (eds.). Cultures and Collections of Algae. Tokyo, Japanese Society of Plant Physiology.

Schmitz, F. 1896. Bangiaceae. Pp. 307-316. In: A. Engler \& K. Prantl (eds.). Die natürlichen Pflanzenfamilien nebst ihren Gattungen und wichtigeren Arten insbesondere den Nutzpflanzen unter Mitwirkung zahlreicher hervorragender Fachgelehrten, Teil 1, Abteilung 2. Leipzig, verlag von Wilhelm Engelmann.

West, J.A.; Zuccarello, G.C.; Scott, J.; Pickett-Heaps, J. \& Kim, G.H. 2005. Observations on Purpureofilum apyrenoidigerum gen. et sp. nov. from Australia and Bangiopsis subsimplex from India (Stylonematales, Bangiophyceae, Rhodophyta). Phycological Research 53(1): 49-66.

West, J.A.; Zuccarello, G.C.; Scott, J.L.; West, K.A. \& Karsten, U. 2007. Rhodaphanes brevistipitata gen. et sp. nov., a new member of the Stylonematophyceae (Rhodophyta). Phycologia 46(4): 440-449.

Wynne, M.J. 2011. A Checklist of Benthic Marine Algae of the Tropical and Subtropical Western Atlantic: thrid revision. Nova Hedwigia 140: $1-166$ 

